\title{
Why Are Trade Agreements More Attractive In The Presence Of Foreign Direct Investment?
}

\author{
Marcelo OlarReaga*
}

\section{INTRODUCTION}

During the last decade, regional integration programs flourished all over the world. The desire to obtain better access to foreign markets under fears of a breakdown of multilateral rules has certainly been one of the main reasons for the move from multilateralism to regionalism in international trade negotiations. At the same time, there has been a rapid increase in international Foreign Direct Investment (FDI) in the developed and developing worlds ${ }^{1}$. Another interesting empirical observation is that North-South integration programs are now in vogue (for example NAFTA, MERCOSUR and the EU recent cooperation treaty, the association agreements between the EU and Central Europe, or Bush's initiative for the Americas). Are these developments related? How does the existence of FDI or Multinational Corporations (MNCs) affect the net gains from Trade Agreements (TA)? This paper focuses on these two questions. An argument often put forward against TA formation in the presence of foreign capital, is that part of the gains from moving towards a single market may be captured by an increase in foreign firms profits, which reduces the interest countries may have in such schemes ${ }^{2}$. This fear has apparently hampered regional integration efforts all over the world, particularly in the 1970's in Latin America ${ }^{3}$.

This paper argues that in the presence of FDI, trade integration schemes tend to be welfare improving. Furthermore, a TA that would be immiserising in the absence of FDI may become welfare-enhancing in the presence of FDI. Thus, it is argued that FDI may cause TA ${ }^{4}$. This may help explain the simultaneous surge in FDI and TA worldwide.

Since BHAGWATI and TiRONI's (1980) study, it has been fully recognised that the existence of foreign capital raises new issues when considering the effects of TA formation on welfare. They show that a move towards a pure trade-creating TA may reduce

* World Trade Organization, Economic Research, 1211 Geneva 21, Switzerland, and CEPR, London, UK. e-mail: marcelo.olarreaga@wto.org. I am greatly indebted to JAIME DE MELo for invaluable supervision. I also gratefully acknowledge very helpful comments by Richard Baldwin, Yves FlüCKIGeR, JeanMarie Grether, Ulrich Kohli, André Sapir and an anonymous referee.

1. Hoffman (1993) notes that since 1985 FDI has been increasing at an average of $27 \%$ per year.

2. See TiRoni (1982).

3. See Hofman (1993), p. 34.

4. Other papers, as MotTA and Norman (1996) reversed the causality to explain «who does economic integration cause FDI?». BALDWIN et al. (1996) provide some European evidence on how the incentives to invest in different countries and regions may be affected by economic integration. 
national welfare in the presence of foreign capital5. BHAGWATI and BRECHER (1980) and BRECHER and BHAGWATI (1981) showed that this surprising result is linked to income redistribution from national-owned factors to foreign-owned capital in the lines of the STOLPER-SAMUELSON theorem.

If the assumptions of the HECKSCHER-OHLIN model used in these previous studies may explain the existence of portfolio investment abroad, it cannot explain the existence of $\mathrm{FDI}^{6}$. Markets where MNCs mainly trade are generally oligopolistic. The existence itself of FDI or MNCs is not so much due to international factor reward differentials, as assumed by the HECKSCHER-OHLIN model, but to market imperfections that ensure larger profits abroad'. Therefore, to explore the effects of TA formation in the presence of FDI, it is preferable to refer to the trade literature on imperfect competition. Olarreaga (1996a) has shown that the welfare effects of trade liberalization in the presence of FDI obtained under perfect competition cannot be extended to imperfectly competitive markets. Unlike in BHAGWATI and BRECHER's work, tariff reductions generally increase welfare in the presence of FDI. The model in this paper can be seen as an extension of Olarreaga (1996a) to the case of reciprocal tariff eliminations (i.e., TA formation). Thus, it basically brings into the analysis the market access aspect into the TA partner's market, which in imperfectly competitive markets has an important dimension. Indeed, if unilateral tariff reductions always decreased home-based firms' profits, this is not necessarily the case when firms face reciprocal tariff reduction given the potential gains in the TA partner's market.

Studies of TA formation in the presence of imperfect competition are rare. HARRIS (1994) notes that «after a decade and a half of effort, the 'new' trade theory has left the regional trade agreement problem virtually untouched ${ }^{8}$. Obviously, the literature on TA formation in the presence of foreign capital in imperfectly competitive environments is even smaller. There are some exceptions. TIRONI (1982) graphically treated the case of a monopolistic industry (one foreign-owned firm) and concluded that indeed foreign firms gains from integration were larger than national welfare gains when the foreign monopolistic firm also behaves monopolistically in the enlarged market, since average costs decrease by more than the average price for consumers. On the other hand, if the foreignowned firm is constrained to behave competitively after the market enlargement, he shows that monopolistic profits obviously disappear and national welfare gains are

5. Obviously aggregate welfare increases due to traditional gains of pure trade-creating TA. The difference between national welfare and aggregate welfare is the same as between Gross National Product and Gross Domestic Product.

6. Note that in the last decade portfolio investment abroad and FDI were both multiplied by 6 , though in $1994 \mathrm{FDI}$ in the world was twice portfolio investment. Figures are from TURNER (1995).

7. As put by Diaz-Alejandro (1970), pure competitive models are unable to explain FDI. For a recent survey of models explaining the existence of MNCs see MARKuSEN (1995).

8. Venables (1987) and BaLDWIN and Venables (1995) show that in a monopolistic competitive industry TA formation increases competition and reduces price-cost margins but the free-entry assumption excludes any focus on the evolution of firms profits. 
larger. Taking a different approach, based on transfer pricing arguments when foreign firms are subsidiaries of a MNC located in the TA partner, RoBson and Wooton (1993) show that all gains of TA formation are captured by foreign firms through income redistribution from tariff revenue to subsidiary's profits.

If RoBson and WoOTON tend to confirm that a large amount of TA gains are captured by home-based foreign firms, their analysis assumes that home-based subsidiaries do have subsidiaries or headquarters in the TA partner ${ }^{9}$. Here I exclude this possibility, and unlike TIRONI, I focus on oligopolistic markets with strategic interactions among firms. Given that the subsidiary issue is excluded from the analysis in this paper, I refer to FDI and MNCs as synonymous.

I show that under imperfect competition, foreign firms do not always benefit from $\mathrm{TA}^{10}$ formation and that national welfare gains may be larger than aggregate welfare gains. However, as in most of the imperfect competition literature, results are ambiguous, but for unusual reasons. Here it is not so much the form of competitive rivalry among MNCs that changes the results, but the initial level of protection in integrating countries.

It is also shown that if initially tariffs are endogenously determined through a political game, then pre-union tariffs are such that national welfare, aggregate welfare and MNCs profits increase after TA formation. This may help explain the rush towards regional integration arrangements, whereas we simultaneously observed an important increase in FDI. It is argued that the rapid increase in FDI and the interest given to North-South integration programs may also be related.

Section 2 explores welfare effects of TA formation in the presence of foreign-owned firms within the simplest model of imperfect competition, i.e. a Cournot model with homogenous goods and linear demand". Section 3 introduces political economy issues to explain welfare and profit changes following the formation of TAs, where initial protection levels are endogenously determined. Section 4 concludes.

\section{WELFARE CHANGES FROM A TA UNDER FDI}

Regional trade agreement (TA) is here seen as a bilateral reduction in tariffs between countries $a$ and $b$. Assume that there is only one firm in each country trading in an international imperfect competitive market. Firm 1 is located in country $a$ and is owned by residents of country $c$ (country $c$ stands for rest-of-the-world). Firm 2 is located in coun-

9. Though they do not focus on regional trade agreements, MARKuSEn, RutHerford and HunTER (1995) show that gains from trade liberalisation are small when sectors are dominated by MNCs due to transfer-pricing.

10. In this paper, TA is seen as a bilateral elimination of tariffs.

11. The robustness of results to different types of market structure is discussed in OlarReaGa (1996b) through simulation exercises. 
try $b$. As I focus on the welfare effects of TA in country $a$, the structure of ownership of firm 2 is irrelevant and is made explicit only when necessary. These two firms compete in $a$ and $b$ 's market. To avoid issues related to trade diversion, I assume that transport costs between $a$ and $b$ and the rest of the world on goods produced by firms 1 and 2 are high enough so that this good is not traded with $c$.

In country $a$ (and $b$ ) there are only two sectors: an imperfectly competitive sector where firms 1 and 2 trade and a perfectly competitive sector where a composite good, $m$, is traded. The imperfectly competitive sector is small in relation to the competitive sector, so that firms 1 and 2 cannot influence factor prices. Factor markets are competitive. For simplicity, I also assume that initially there are no tariffs on the composite good and that tariffs on the imperfectly competitive traded goods are specific. The price of the composite good (which is fixed by world markets) is used as numéraire.

Assume firms strategic choice variables are quantities sold in each market. To simplify the algebra, I assume that goods traded in the imperfect competitive market are homogeneous, and that both firms have identical constant marginal costs, noted $m c$, and a fixed cost, noted $F$. The price of the homogeneous good in countries $a$ and $b$ are respectively noted $p^{a}$ and $p^{b}$. Consumers' utility function is quasi-linear in the composite good and quadratic in the quantities consumed of the imperfectly competitive traded good, in both countries:

$$
\begin{aligned}
& u^{a}=\alpha\left(q_{1}^{a}+q_{2}^{a}\right)-\beta / 2\left(q_{1}^{a}+q_{2}^{a}\right)^{2}+m^{a} \\
& u^{b}=\alpha\left(q_{1}^{b}+q_{2}^{b}\right)-\beta / 2\left(q_{1}^{b}+q_{2}^{b}\right)^{2}+m^{b}
\end{aligned}
$$

where $a \beta>0$ are parameters. Inverse demand functions for the homogenous good are then given by:

$$
\begin{aligned}
& p^{a}=\alpha-\beta\left(q_{1}^{a}+q_{2}^{a}\right) \\
& p^{b}=\alpha-\beta\left(q_{1}^{b}+q_{2}^{b}\right)
\end{aligned}
$$

Again, to simplify assume that initial tariffs in both countries are identical, and noted $t=t^{a}=t^{b}$. This is a sensible initial assumption given symmetry conditions of demand and supply. Its implications are discussed in section 3 where we allow for different initial tariffs.

Under these assumptions firms strategic choice in $a$ 's market is taken independently of choice in $b$ 's market and operating profits of firms 1 and 2 are given by:

$$
\begin{aligned}
& \pi_{1}=p^{a} q_{1}^{a}+p^{b} q_{1}^{b}-m c\left(q_{1}^{a}+q_{1}^{b}\right)-t q_{1}^{b} \\
& \pi_{2}=p^{a} q_{2}^{a}+p^{b} q_{2}^{b}-m c\left(q_{2}^{a}+q_{2}^{b}\right)-t q_{2}^{a}
\end{aligned}
$$


To obtain the optimal Cournot quantities, one differentiates $\pi_{l}$ with respect to the strategic variables of each firm ( $q_{\mathrm{i}}^{a}$ and $q_{\mathrm{i}}^{b}$ for firm $\left.i=1,2\right)$ equalise them to zero and solve simultaneously for the optimal quantities. Then by substituting the optimal quantities into (3) one gets the equilibrium prices and by substituting into (5) and (6) the optimal profits. The pre and post-TA market equilibria are summarised as follows ${ }^{12}$ :

Pre-TA market equilibrium

$$
\begin{gathered}
q_{1}^{a}=q_{2}^{b=}=\frac{\alpha-m c+t}{3 \beta} ; q_{2}^{a}=q_{1}^{b}=\frac{\alpha-m c-2 t}{3 \beta} ; p^{a}=p^{b}=\frac{\alpha+2 m c+t}{3} \\
\pi_{1}=\pi_{2}=\frac{5 t^{2}-2(\alpha-m c) t+2(\alpha-m c)^{2}}{9 \beta}
\end{gathered}
$$

Post-TA market equilibrium

$$
\begin{gathered}
q_{1}^{a}=q_{2}^{b}=q_{2}^{a}=q_{1}^{b}=\frac{\alpha-m c}{3 \beta} ; \quad p^{a}=p^{b}=\frac{\alpha+2 m c}{3} \\
\pi_{1}=\pi_{2}=\frac{2(\alpha-m c)^{2}}{9 \beta}
\end{gathered}
$$

Given symmetry of demand, equal initial tariff protection and constant marginal cost, prices in both countries are equal in the pre and post-TA equilibria. This allows us to see TA either as a mutual elimination of tariffs in segmented markets or as a move from segmented to integrated markets. Indeed, as discussed by SMith and Venables (1991), a mutual elimination of tariffs does not necessarily imply a move from segmented to integrated markets. Even when both tariffs are zero, markets could still be segmented if, for different reasons, there is no consumer arbitrage between countries. This issue is avoided here, though whenever we assume that initially tariffs are different, and therefore prices differ across countries, it becomes a relevant issue. If this is the case, then I assume markets are segmented ${ }^{13}$.

Changes in prices and quantities following the formation of a TA are:

$$
\Delta q_{1}^{a}=\Delta q_{2}^{b}=-\frac{t}{3 \beta} \quad ; \quad \Delta q_{2}^{a}=\Delta q_{1}^{b}=\frac{2 t}{3 \beta} \quad ; \quad \Delta p^{a}=\Delta p^{b}=-\frac{t}{3}
$$

12. We calculate pre and post-TA equilibrium values in order to work out the discrete changes. Partial differentiation may be misleading when large tariffs changes are involved.

13. BRANDER and SPENCER (1984), among others, forcibly argue for the relevance of the segmented market assumption. 
Thus total quantities sold by firm 1 increase, $\Delta \cdot q_{\mathrm{i}}^{a}+\Delta q_{\mathrm{i}}^{b}=t /(3 \beta)>0$, though quantities sold by firm 1 in market $a$ fall; $q_{\mathrm{i}}^{a}$ falls following the TA formation, as firm 2 reaction function in country $a$ shifts up following the elimination on $a$ 's tariff. Since reaction functions slope down, this induces an increase in quantities sold by firm 2 in country $a$, and a reduction of quantities sold by firm 1 in this country. Symmetry implies that $q_{\mathrm{i}}^{b}$ increases and $q_{2}^{b}$ falls. Moreover, total consumption in country $a$ (and $b$ ) increases. The reason is that in country $a$, the slope of firm 1 reaction function is larger than 1 in absolute value (actually, it is equal to -2 ); then an upwards shift of firm 2 reaction function necessarily implies a larger increase of firm 2 quantities than the fall of firm 1 sales in this country ${ }^{14}$.

$$
\Delta \pi_{1}=\Delta \pi_{2}=t \frac{2(m c-\alpha)-t}{9 \beta}+4 t \frac{\alpha-m c-t}{9 \beta}
$$

where the first term represents the change in domestic market profits and is always negative since $\alpha$ is necessarily higher than $m c$ if producers are to enter the market. The second term represents the change in profits made in the foreign market and is positive if $t$ is not too large, i.e. $t<\alpha-m c$. Actually this is the case since the prohibitive tariff (i.e., the trade existence condition) is smaller than $\alpha-m c$. To obtain the prohibitive tariff solve in country $a[b], q_{2}^{a}>0\left[q_{1}^{b}>0\right]$ for $t$, It yields:

$$
t<\frac{\alpha-m c}{2}=t^{p r}<\alpha-m c
$$

Then firms total profit variation is ambiguously signed; profits of firm 1 in $b$ 's market increase whereas in market a they fall. However, one can solve $\Delta \cdot \pi>0$ for $t$ in equation (10) to obtain the maximum initial tariff level for which firm profits increase:

$$
t^{\pi}>\frac{2}{5}(\alpha-m c)
$$

Figure 1a illustrates the operating profit level given by (7) for different levels of initial tariffs ${ }^{15}$. It shows, for example, that if the initial tariff level is $t^{\pi}$ then profits do not change when $a$ and $b$ integrate (i.e., $t=0$ ). The idea is that when tariffs are high then firm

14. It could be easily verified that stability conditions are satisfied.

15. Recall that the initial tariff level is equal in both countries. 
1 pre-TA profits in country $a$ are also important since it can almost behave as a monopolist in this market. On the other hand, firm 1 profits in $b$ are small since it faces a large cost when selling in $b$ 's market associated with the high pre-TA tariff level. Then if $a$ and $b$ integrate (i.e. $t=0$ ), firm 1 profits in country $a$ would fall by a large amount due to increase competition by firm 2 that faces significantly smaller cost in selling in $a$ after the TA is formed. But for the same reason firm 1 profits in $b$ increase importantly.

If the initial tariff was $t^{\pi}$, then the two conflicting effects on firm 1 profits cancel out, and the level of profits do not change following the TA formation. Figure 1a also shows that firm 1 profits can fall after $a$ and $b$ integrate, if the initial tariff is sufficiently large (i.e., $t>2(\alpha-m c) / 5)$ This would be the case if the initial tariff equals the prohibitive tariff, $t=(\alpha-m c) / 2$, in which case firms initially behave as monopolists in the country where they are based. This contradicts the idea that quite generally MNCs benefit from TA formation. The increase in competition among firms may actually induce profits to fall. However, as will be discussed later, under the assumptions used here this is very unlikely to occur since the initial tariff needs to be dramatically high ${ }^{16}$.

Figure 1 a: Firms Profits

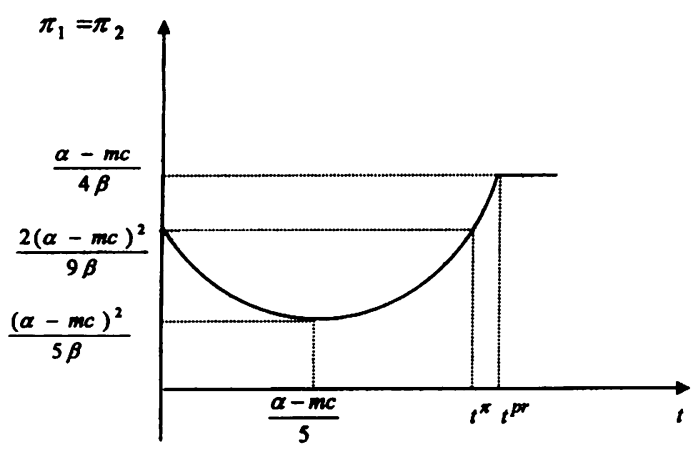

\subsection{WELFARE EFFECTS OF TA FORMATION}

To estimate welfare effects of TA formation, one needs to calculate the pre and post-TA levels of utility to account for large tariff changes generated by the bilateral elimination of tariffs. Partial differentiation of the utility function may be misleading given its nonlinearity.

Moreover, it is necessary to distinguish between national and aggregate welfare, as in BrECHER and BHAGWATI $(1980,1981)$. The distinction between national and aggregate welfare is the same as between Gross National Product and Gross Domestic Product, i.e.

16. Figure la also shows the initial tariff level that minimise firms profits. To obtain it, differentiate total profits with respect to $t$ and then solve for $t$. It yields $t=(\alpha-m c) / 5$. 
national welfare excludes income of foreign-owned factors, whereas aggregate welfare includes it. Thus, in our setting, national welfare excludes firm 1 [2] profits in country $a$ [b] whereas aggregate welfare includes them. The idea is that foreign firms profits are repatriated and therefore should not be considered as part of national welfare.

Let us focus on the welfare effects in country $a^{17}$. This allows us to introduce the following notation for the level of utility: $u_{j}^{k}$ denotes the level of utility where $k=n a, a g$ determines whether utility is estimated at the national or aggregate level ( $n a$ stands for national and $a g$ for aggregate) and subscript $\mathrm{j}=$ pre, pos determines whether utility is evaluated before or after the formation of the TA (pre stands for pre-TA, and pos for post-TA).

To estimate the pre-TA level of utility, one needs to substitute the optimal quantities in (7) into (1). This yields:

$$
u_{p r e}^{k}=\frac{1}{18 \beta}\left(8 \alpha^{2}-4 \alpha m c-2 \alpha t-4 m c^{2}-4 m c t-t^{2}\right)+m_{p r e}^{k}
$$

where $m_{p r e}^{k}$ is the level of consumption of the composite good. The distinction between the national and aggregate pre-TA level of utility is determined by the difference between the level of consumption of the composite good at the national and aggregate level (i.e., $m_{p r e}^{k}$ ). That is, to evaluate the level of welfare, one needs to determine the demand for the composite good when profits are repatriated (national welfare) and when they remain in country $a$. Given the quasi-linear utility function in (1), $m_{\text {pre }}^{k}$ is determined by the residual income once consumers have spent their income in the consumption of goods 1 and 2 . To see this maximise the utility function in (1) under a budget constraint with respect to $m_{\text {pre }}^{k}$ (recall that the price of the composite good is used as numéraire and units are chosen so that it is equal to one). This yields:

$$
m_{p r e}^{k}=y_{p r e}^{k}-p^{a}\left(q_{1}^{a}+q_{2}^{a}\right)
$$

where $y_{p r e}^{k}$ is national or aggregate income. The difference, again, is foreign firms' profits. Substituting (14) into (13), we obtain the level of pre-FTA utility as a function of tariffs and income (aggregate or national):

$$
u_{p r e}^{k}=\frac{1}{18 \beta}\left(4[\alpha-m c]^{2}-t[4 \alpha-m c-t]\right)+y_{p r e}^{k}
$$

17. Given the symmetry assumptions, results are identical for country $b$. 
The level of utility in the post-TA formation is obtained by setting $t=0$ in (15). This yields:

$$
u_{p o s}^{k}=\frac{1}{18 \beta}\left(4[\alpha-m c]^{2}\right)+y_{p o s}^{k}
$$

Now define the change in welfare as $\Delta u^{k}=u_{p o s}^{k}-u_{p r e}^{k}$ Thus:

$$
\Delta u^{k}=\frac{1}{18 \beta}(t[4 \alpha-m c-t])+\Delta y^{k}
$$

To be able to sign (17), one needs to evaluate $\Delta y^{k}$ at the national and aggregate level. In this setting, given that factor prices are kept constant, the change in national income is just given by the change in tariff revenue and the change in aggregate income is given by the change in tariff revenue plus the change in firm 1 profits. Thus:

$$
\begin{gathered}
\Delta y^{n a}=-t q_{2}^{a}=-t \frac{\alpha-m c-2 t}{3 \beta} \\
\Delta y^{a g}=-t q_{2}^{a}+\Delta \pi_{1}=-t \frac{\alpha-m c-2 t}{3 \beta}+t \frac{2(m c-\alpha)-t}{9 \beta}+4 t \frac{\alpha-m c-t}{9 \beta} \\
=t \frac{-\alpha+m c+t}{9 \beta}
\end{gathered}
$$

Finally, substituting (18) and (19) into (17) and after some simplifications, one obtains:

$$
\begin{gathered}
\Delta u^{n a}=t \frac{2(m c-\alpha)+11 t}{18 \beta} \\
\Delta u^{a g}=t \frac{2(\alpha-m c)+t}{18 \beta}
\end{gathered}
$$


Equation (20) suggests that the change in national welfare may be negative following the formation of a TA. Indeed, by setting the right hand side of (20) larger than zero, and solving for $t$ it yields:

$$
t>\frac{2(\alpha-m c)}{11}=t^{\text {cuma }}
$$

where $t^{\text {cuna }}$ is the minimum initial tariff for which the formation of a TA increases welfare at the national level.

Equation (21) suggests that the change in aggregate welfare is always positive since $\alpha-m c>0$ if firms are to enter the market. It follows that $t^{\text {cuag }}=0$, where $t^{\text {cuag }}$ is the minimum tariff for which aggregate welfare increases after the formation of a $\mathrm{TA}^{18}$.

Figure $1 \mathrm{~b}$ illustrates the change in aggregate and national welfare as a function of the initial tariff level among partners (i.e., equations (20) and (21). The change in aggregate welfare is monotonically increasing with the level of the initial tariff. Thus, aggregate welfare always increases following the formation of a TA, regardless of the initial tariff among potential members. The change in national welfare is non-negative, if and only if, $t \geq t^{\text {cuna }}$ which indicates that for very low initial tariffs among potential members there may be some welfare losses at the national level. This is due to the loss in tariff revenue that is redistributed to foreign firms' profits and therefore not included in national welfare.

For very high tariffs the change in national welfare may be larger than the change in aggregate welfare (i.e., if $t \geq 2(\alpha-m c) / 5=t \pi)$. The reason is that for initial tariffs that are higher than $t \pi$, then firms profits decline as previously discussed. Thus, as the difference between national and aggregate welfare is given by foreign firms' profits, this implies that the change in national welfare must be higher than the change in aggregate welfare, whenever the change in foreign firms' profits are negative.

These results may be seen as confirming the fear that an important share of TA gains are captured by MNCs even in the absence of strategic transfer pricing issues. They also confirm results in perfect competition, though the mechanisms at work are different. In BHAGWATI and TIRONI (1980) the result is obtained through income redistribution from foreign factors to national factors through the STOLPER-SAMUELSON theorem, whereas here redistribution goes from tariff revenue to MNCs profits.

18. We exclude import subsidies. 
Figure 1b: Change in national and aggregate welfare

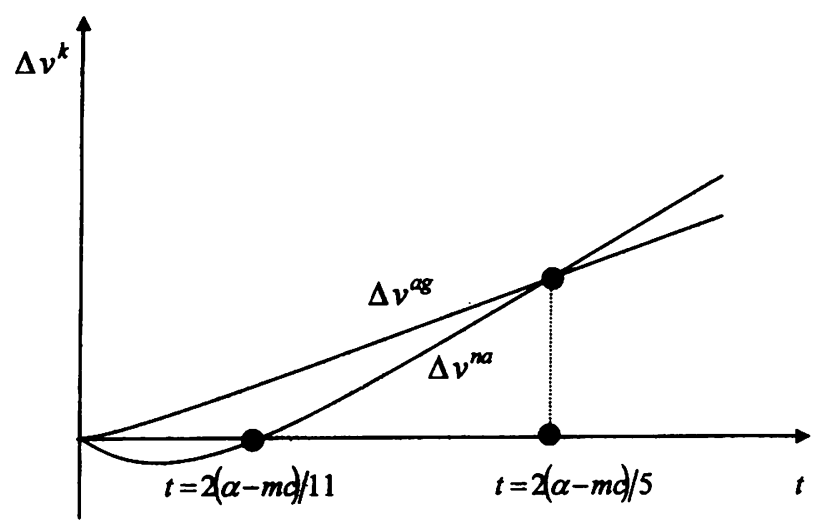

However, one should note that MNCs and nationals' (i.e., domestic residents) interest in the formation of a TA are not directly antagonistic, though there is income redistribution from nationals' tariff revenue to firms profits. If the initial tariff is in the range $2(\alpha-m c) / 11<t<(\alpha-m c) / 5$, then both nationals and MNCs gain from TA formation. This is the case, if for example governments initially fixed tariffs by maximising tariff revenue or aggregate welfare.

If governments set tariffs in order to maximise tariff revenue, then their optimisation problem is given by:

$$
R=\max _{t} t q_{2}^{a}
$$

where $R$ is tariff revenue. To solve this problem, one needs to substitute the optimal value of $q_{2}^{a}$ in equation (7) into (23); then partially differentiate $R$ with respect to $t$ and equalise the result to zero. Solving this for $\mathrm{t}$, yields the tariff revenue maximising tariff, noted $t^{t r}$ :

$$
t^{t r}=\frac{\alpha-m c}{4}
$$

Note that $t^{\text {cuna }}<t^{t r}<t \pi$, which implies that if the initial tariff is equal to $t^{t r}$, then both MNCs and nationals benefit from the formation of a TA.

If the government initially maximises aggregate welfare, then the optimal tariff, denoted $t^{a g}$, is obtained by partially differentiating (15) when $k=a g$ with respect to $t$. 
Recall that the change in aggregate welfare is given by the change in tariff revenue (i.e $\partial R / \partial_{t}{ }^{a}$ ) plus the change in firm 1 profits in market $a$ (as we are looking for the optimal aggregate tariff in country $a$ and markets are segmented). This yields:

$$
\frac{\partial u^{a g}}{\partial t}=\frac{\alpha-m c-3 t}{3 \beta}=0
$$

Solving (25) for $t$, one obtains $t^{a g}=(\alpha-m c) / 3$ which is larger than $t^{\text {cuna } a}$ and smaller than $t^{\pi}$, implying that both nationals (i.e., domestic residents) and firm 1 profit increase following the formation of a TA if the initial tariff is $t^{a g}$.

On the other hand, if the government initially maximises national welfare, then the optimal tariff is obtained in a similar way except that the change in firm 1 profits should not be included as part of the change in national income. Then the optimal national tariff, denoted $t^{n a}$, is given by $t^{n a}=(\alpha-m c) / 11$. This in turn implies that, following the formation of a TA, national welfare falls (as $t^{\text {cuna }}>t^{n a}$ ) whereas MNCs profit increases (as $t^{\pi}>t^{n a}$ ).

Results of this section can be summarised as follows:

$$
t^{\pi}>t^{a g}>t^{t r}>t^{\text {cuna }}>t^{n a}>t^{\text {cuag }}=0
$$

Therefore, the level of initial tariffs is crucial to detect who gains from TA ${ }^{19}$. Determination of initial tariffs is discussed in section 3, where it is shown that if tariffs are politically determined then the initial tariff is $t^{a g}$. Then, as indicated by (26), both national welfare and foreign-owned firms profits increase. This would imply that both nationals and home-based MNCs do not have conflicting interest when envisaging $a \mathrm{TA}$.

In Olarreaga (1996b), it is shown that the result summarised in (26) is robust to other types of competitive rivalry, production costs differentials and differences in demand structure, as long as product substitutability is not too small. To abstract from this case seems reasonable as the focus here is on oligopolistic markets, and with low degrees of product substitutability results are closer to the ones obtained previously for monopolistic markets by TIRONI (1982) ${ }^{20}$.

19. This inequality is also verified in a setting with $n$ firms per country and $m$ countries if the number of firms per country is not too large. If the number of firms per country is large and considering that under Cournot competition perceived marginal revenue is below true marginal revenue, then when rising tariffs, domestic firms sell 'too much' in the domestic market and the domestic price may go down. In the two country world we can show that for the inequality to hold the number of firms per country has to be smaller than 5 .

20. Further, in this paper it is assumed that firms do not change their competitive behaviour after market integration. OlarReaGA (1996b), shows that integration, in the sense of a bilateral tariff reduction will not lead to more collusive behaviour among firms, except under rather implausible assumptions. 


\section{WHY A SIMULTANEOUS RISE IN FDI AND TA?}

The importance of the relative initial tariff differential has been discussed in section 2 . In this section, I focus on the determination of initial tariffs to explain why some types of TA are more likely to be formed than others in the presence of FDI.

If the government in country $a$ is only concerned by nationals social welfare, then it will set a tariff equal to $t^{n a}$ and the formation of a TA is immiserising under all possible scenarios considered in section $2\left(t^{\text {cuna }}>t^{\text {na }}\right)$ MNCs benefit from the market enlargement $\left(t^{\pi}>t^{n a}\right)$. It is then difficult to explain within the model, the decision by country $a$ to form a TA with $b$, if the government is only concerned by national welfare and the formation of the enlarged market is nationally immiserising.

An alternative assumption is that given revenue constraints in developing countries, governments may set tariffs at their tariff revenue maximising level. In this case, the initial tariff $\left(t^{t r}\right)$ is larger than $t^{\text {cuna }}$. Then TA formation increases national welfare and MNCs profits. However, one cannot explain within the model the formation of TA since the government loses: in trade-creating TA, assumed throughout this paper, there is no tariff revenue left. The same conclusion is reached if we assume that the governments objective function is the sum of tariff revenue and national welfare. Moreover, in this case the tariff-revenue-concerned government initially fixes a tariff below $t^{\text {tuna }}$ and national welfare falls when the TA is formed.

However, the literature on trade and political economy has an alternative explanation to the formation of tariffs. Firms lobby for protection in order to ensure larger profits, whereas governments (or political parties) respond to firms demand for different possible reasons. Consider, as in Grossman and Helpman (1994), that the incumbent government accepts lobbies' contributions to finance their political campaign. Then to apply directly Grossman and HeLPMAN's political equilibrium for tariffs to our setting we need to assume that there exist several MNCs operating in the host country ${ }^{21}$. The utility function is quasi-linear on $m^{a}$ and additive and quadratic on quantities produced by MNCs:

$$
u^{a}=\sum_{j} \alpha\left(q_{1}^{a}+q_{2}^{a}\right)_{j}-\beta\left(q_{1}^{a}+q_{2}^{a}\right)_{j}^{2}+m^{a}
$$

The additive form allows us to abstract from substitution effects in consumption between goods produced in the host-country by different MNCs. On the other hand, we still assume that in each $j$ sector the home based MNC (firm $1_{j}$ ) faces competition from a foreign competitor (firm $\left.2_{j}\right)$. Assuming that all firms $\left(1_{j}\right.$ and $\left.2_{j}\right)$ have identical marginal

21. If there is only one firm, the endogenous tariff will be set through a bargaining process so that the non-cooperative equilibrium of GROSSMAN and HELPMAN may not apply. 
costs and given demand symmetry, all politically determined tariffs are equal. Then, as in BERNHEIM and WHINSTON (1986), assume that all lobbies (MNCs) move simultaneously, as multiple principals in the political game, by facing their common agent - the government - with contribution schedules conditioned on the vector of domestic prices ${ }^{22}$. In the first stage of the political game, lobbies announce their contribution schedule to the government and in the second stage the government sets trade policy and lobbies donations are paid ${ }^{23}$. Then the government in country $a$ chooses tariffs by maximising:

$$
w^{n a}=\sum_{j} C_{j}+u^{n a}
$$

where $C_{j}$ is the contribution schedule of the MNC in sector $j ; w^{n a}$ is the government objective function and $u^{n a}$ the national utility function as before ${ }^{24}$. Then, if as in BERNHEIM and Whinston (1986) contribution schedules are truthful, $\partial C_{j} / \partial t_{j}=\partial \pi_{1, j} / \partial t_{j}$. That is, the marginal cost for the MNC of a slight increase in tariffs (i.e., the increase in contributions to the government) equals its marginal gain (i.e., the increase in MNC's profits).

We then have that the first order condition to the government problem in sector $j$ is given by:

$$
\frac{\partial w^{n a}}{\partial t_{j}}=\frac{\partial \pi_{1 . j}}{\partial t_{j}}+\frac{\partial u^{n a}}{\partial t_{j}}=\frac{\partial u^{a g}}{\partial t_{j}}
$$

The problem of the politically concerned government is then identical to the problem of the government concerned with social aggregate welfare. We then have that the politically determined tariff equals $t^{n a}$. In section 2 we have seen that $t^{n a}>t^{\text {cima }}$. Then, if the initial tariff was politically determined, the formation of a TA increases national welfare. Equivalently and under the same conditions, it increases MNCs profits (i.e. $t^{\pi}>t^{a g}$ ). Thus, under these assumptions the formation of a TA could be endogenously explained since all agents in the economy benefit from it.

Now, within this setting we explain why the increase in FDI in the last decade may have raised the interest that host-countries had in TA. Suppose that initially country $a$ had no firms producing the imperfectly traded good and that all foreign firms (owned by residents in country $c$ ) are located in country $b$ and selling in both $a$ and $b$ markets. Then the (endogenous) tariff in $a$ will be given by $t^{n a}$. The reason is that as there are no firms in $a$,

22. Note that here there is no quid-pro-quo FDI as in BHAGwATI (1987) where foreign-owned firms lobby for lower protection.

23. BALDWIN (1993) suggests that the enforceability assumption (i.e., lobbies pay after trade policies are announced) may not be necessary in a repeated game setup.

24. To simplify, I assume that social welfare and contributions have the same weight in the government objective function. 
then there are no contributions to the government. The objective function of the government is then given by:

$$
\frac{\partial w^{n a}}{\partial t_{j}}=\frac{\partial \pi_{1, j}}{\partial t_{i}}+\frac{\partial u^{n a}}{\partial t_{i}}=0+\frac{\partial u^{n a}}{\partial t_{j}}=\frac{\partial u^{n a}}{\partial t_{i}}
$$

Thus, the problem of the politically concerned government in the absence of contributing firms is identical to the problem of a national welfare maximiser government. Thus, the optimal endogenous tariff in this case is $t^{m a}$. The rationale for a tariff in the absence of firms producing in countries $a$ is based on terms of trade effects. Note that $t^{n a}$ is smaller than $t^{\text {cuna }}$ implying that national welfare would fall following the formation of a TA. Country $a$ would then rationally refuse any trade integration program. The reason is that the terms of trade loss implies that the consumer gain cannot overweight the tariff revenue loss.

Then assume that $a$ host one foreign-owned firm. The endogenous tariff in country $a$ would be $t^{\text {cama }}>t^{a g}>t^{\pi}$. Thus, both MNCs and nationals in $a$ would benefit from the creation of TA, which is then endogenously explained. This implies that after the entry of FDI, countries $a$ and $b$ gain from a mutual elimination of tariffs (assuming that the same political game in country $b$ and that all firms in country $b$ are owned by residents in country $c$ ). The reason is that contributions by the foreign firm to country $a$ 's political process compensate the government in country $a$ for the terms of trade loss due to the formation of the TA. Therefore, the presence of FDI makes TA more attractive which may explain the simultaneous increase of these two phenomena in the last decade.

Alternatively, one can explain the simultaneous rise in FDI and TA formation by comparing incentives to form a TA when all firms are owned by domestic residents, to incentives when firms are owned by foreign residents. FDI can then be seen as foreigners acquiring domestic firms. When all firms are owned by domestic residents, then the problem of the politically concerned government in country $a$ becomes ${ }^{25}$ :

$$
\frac{\partial w^{n a}}{\partial t_{j}}=\frac{\partial w^{a g}}{\partial t_{j}}=\frac{\partial \pi_{1, j}}{\partial t_{j}}+\frac{\partial u^{a g}}{d t_{j}}=\frac{5(\alpha-m c)-7 t}{9 \beta}=0
$$

Solving (31) for $t$, yields $t^{*}=5(\alpha-m c) / 7$. The reason why the initial tariff is higher in this case than in the case where firms are foreign owned, is that firms profits enter twice into the governments objective function: first as contributions to the government as before,

25. Note that in this case aggregate welfare equals national welfare as there is no FDI. 
and then as income to nationals into the welfare function as the firms are domestically owned. Note that $t^{*}>t^{\pi}$ implies that firms in the imperfectly competitive sector will loose from the formation of the TA, given that the initial tariff is sufficiently high. Thus, the formation of the TA will be politically unfeasible if all firms are owned by domestic residents.

On the other hand, if firms are foreign owned, the optimal initial tariff is $t^{a g}$, and as seen before, both MNCs and national will benefit from the creation of a TA, which will then be politically feasible.

If these interpretations of tariff setting are plausible, one has a potential clue to the observation of increasing FDI and interests in TA noted in the introduction. The increasing presence of FDI in developing countries may explain the rising interest for regional trade arrangements between the developed and developing world. To see this, just assume that country $a$ is a developing country with initially no foreign firm producing in its territory. FDI to the developing country will then make the prospects of a TA more attractive.

\section{CONCLUDING REMARKS}

An argument often put forward against TA formation in the presence of FDI, is that gains from TA are captured by foreign-owned firms, whereas national welfare is unchanged or falls. It is shown that this line of reasoning is not justified when firms trade in oligopolistic markets. Under reasonable assumptions both national welfare and foreignowned firms profits gain from the creation of an enlarged market. It follows that if trade policies are endogenously formed, then the increase in FDI and the number of regional integration arrangement in the last decade are probably related facts. Indeed, if foreignowned firms gain from TA formation, they will tend to lobby in the host country for the formation of this enlarged market. As shown in section 5, if in the absence of FDI the national government has no interest in forming a TA (because initial tariffs would already be relatively low), after the entry of FDI, this possibility becomes more attractive and both nationals (i.e., domestic residents) and foreign-owned firms gain from it.

If it was often suggested that TA formation attracted FDI due to the prospects of higher profits in larger markets, this paper shows that the reverse is also true: FDI attracts TA due to the prospects of higher gains for nationals in the presence of FDI.

The paper also helps explain why North-South trade integration programs emerged in the last decade, based on the increasing presence of North FDI in the South. The idea is that if endogenous tariff are equal then both regions gain from integration, whereas if tariffs are sufficiently different one country may lose. FDI from the North to the South tend to equalise initial tariffs and, therefore, both regions gain from TA formation. Again, FDI attracts TA. 


\section{REFERENCES}

Baldwin, R. E. (1995), «A Domino Theory of Regionalism», in R. E. Baldwin, J. KiAnder and P. HaARPANTA, eds.: Expanding membership of the European Union, Cambridge University Press, Cambridge.

BAldwin, R. E., R. Forslid and J. I. HAALAND (1996), «Investment creation and diversion in Europe», The World Economy, 19 (6), pp. 635-659.

Baldwin, R. E. and A. Venables (1995), «Regional Economic Integration»; in G. Grossman and K. Rogoff, eds.: Handbook of International Economics III, North Holland, Amsterdam.

Bernheim, B. D. and M. D. Whinston (1986), «Menu Auctions, Resource Allocation and Economic Influence»; Quarterly Journal of Economics, 101 (1), pp. 1-31.

Bhagwati, J. N. (1987), «Quid Pro Quo DFI and VIE: A Political-Economy-Theoretic Analysis»; International Economic Journal, 1 (1), pp. 1-14.

Bhagwati, J. N. and R. BRECHER (1980), «National Welfare in an Open Economy in the Presence of Foreign-Owned Factors of Production»; Journal of International Economics, 10 (1), pp. 103-115.

Bhagwati, J. N. and E. Tironi (1980), «Tariff Change, Foreign Capital and Immiserization»; Journal of Development Economics, 7 (1), pp. 71-83.

Brander, J. A. and B. J. Spencer (1984), «Tariff Protection and Imperfect Competition»; in H. KIERzKowsKI, ed.: Monopolistic Competition and International Trade, Oxford University Press, Oxford.

Brecher, R. and J. N. Bhagwati (1981), «Foreign Ownership and the Theory of Trade and Welfare»; Journal of Political Economy, 89 (3), pp. 497-511.

Eaton, J. and G. Grossman (1986), «Optimal Trade and Industrial Policy Under Oligopoly», Quarterly Journal of Economics, 101 (2), pp. 383-406.

Diaz-Alejandro, C. (1970), «Direct Foreign Investment in Latin America; in: C. KIndleberger, ed., The International Corporation, MIT Press, Boston.

Dick, A. R. (1993), «Strategic Trade Policy and Welfare: the empirical consequences of cross-ownership»; Journal of International Economics, 35 (3/4), pp. 227-249.

Grossman, G. and E. Helpman (1994), «Protection for Sale», American Economic Review, 84 (4), pp. 833-850.

Harris, R. (1994), «Customs Union Theory in Oligopoly», Simon Fraser University Discussion Papers \# 94-09.

Harrison, G. W., T. F. Rutherford and I. Wooton (1993), «An alternative Welfare Decomposition for Customs Unions»; Canadian Journal of Economics, 26 (4), pp. 961-968.

HodARA, I. (1992), «Comentarios a 'Qué es el MERCOSUR?'», IEERAL document, CERES, Montevideo.

HoffMan, A. C. (1993), «Inversión Extranjera Directa e Integración Regional: la experiencia reciente de América Latina y el Caribe»; Industrialización y Desarrollo Tecnológico, \# 14, United Nations, Santiago de Chile. 
Markusen, J. (1981), «The distribution of gains from bilateral tariff reductions»; Journal of International Economics, 11 (4), pp. 553-572.

Markusen, J. (1995), «The Boundaries of Multinational Enterprises and the Theory of International Trade» Journal of Economic Perspectives, 9 (2), pp. 169-189.

MotTa, M. and G. Norman (1996), «Does Economic Integration cause Foreign Direct Investment», International Economic Review, 37 (4), pp. 757-784.

Olarreaga, M. (1996a), "Tariff Reductions in the Presence of Foreign Direct Investment»; Review of International Economics, 4 (3), pp. 263-275.

Olarreaga, M. (1996b), Essays on trade policy in the presence of foreign capital, PhD dissertation \# 439, SES Faculty, University of Geneva.

Robson, P. and I. Wooton (1993), «The Transnational Enterprise and Regional Economic Integration» Journal of Common Market Studies 31 (1), pp. 71-90.

Smith, A. and A. Venables (1991), «Economic Integration and Market Access»; European Economic Review, 35 (2/3), pp. 388-395.

Tironi, E. (1982), «Customs Union Theory in the Presence of Foreign Firms»; Oxford Economic Papers, 34 (1), pp. 150-171.

Turner, P. (1995), «Capital Flows in Latin America: a new phase», BIS Economic Papers, \# 44.

Venables, A. (1987), «Customs Union and Tariff Reform under Imperfect Competition»; European Economic Review, 31 (1/2), pp. 103-110.

\section{SUMMARY}

This paper argues that interests of nationals (i.e., domestic residents) and owners of home-based foreign capital in the formation of a Trade Agreements (TA) are not antagonistic, except under rather particular assumptions on initial tariffs among potential members. Further, if initial tariffs are endogenously determined through an industrylobbying process, then TA that would have been immiserising in the absence of Foreign Direct Investment (FDI), may be welfare-enhancing in the presence of foreign-owned firms. The rationale is linked to the effect that the entry of FDI has on the pre-TA tariff, through contributions to the incumbent government. These results may help explain recent integration programs between developed and developing countries.

\section{ZUSAMMENFASSUNG}

Dieser Artikel zeigt, dass die Interessen an der Bildung von Freihandelsabkommen von Einheimischen und von Besitzern von im Land investiertem, ausländischen Kapital nicht entgegengesetzt sind, ausser unter besonderen Annahmen über anfängliche Zölle zwi- 
schen den potentiellen Handelspartnern. Wenn die anfänglichen Zölle durch einen Industrie-Lobbying Prozess endogen bestimmt wurden, haben Freihandelsabkommen ohne Foreign Direct Investment (FDI) einen negativen Einfluss auf den Wohlstand, solche mit FDI jedoch eine positiven. Dieses Ergebnis hängt mit dem Einfluss, den FDI-Ströme auf die anfäglichen Zölle haben, zusammen. Diese Resultate könnten dazu beitragen, die jüngsten Integrationsprogramme zwischen Entwicklungsländern und entwickelten Staaten zu erklären.

\section{RESUME}

Ce papier montre que les intérêts des nationaux et des propriétaires de capital étranger sur sol domestique ne sont pas forcément antagoniste lors de la formation d'un accord commerciale. Plus important, si les tarifs sont déterminés de façon endogène à travers un procesus de lobbying, alors un accord commercial qui aurait diminué le bien-être en absence d'Investissement Direct, va l'augmenter en presence de celui-ci. La raison est liée à l'effet que l'entrée de capital étranger a sur les tariff avant la signature de l'accord commercial, à travers les contribution des groupes de pressions au gouvernement. Ces résultats peuvent aider à expliquer les programmes d'intégration qui ont eu lieu récemment entre pays en voie de développement et pays développés. 
. 